\title{
Karakteristik Penumpang Angkutan Umum Kota Trayek Sudiang - Sentral Kota Makassar
}

\author{
Stanis Alfrian Samban ${ }^{\star 1}$, Astry Wahyuni Mangoli ${ }^{\star 2}$, Rais Rachman ${ }^{\star 3}$, H. Nur Ali ${ }^{\star 4}$ \\ *1,2 Mahasiswa Prodi Teknik Sipil, Universitas Kristen Indonesia Paulus, Makassar, Indonesia \\ alfriansamban@yahoo.com,wahyunimangoli@gmail.com \\ *3,4 Dosen Prodi Teknik Sipil, Universitas Kristen Indonesia Paulus, Makassar, Indonesia \\ Rais.Rachman@gmail.com,nurali.mt@gmail.com
}

\begin{abstract}
ABSTRAK
Ukuran pelayanan yang baik adalah pelayanan yang aman, cepat, murah dan nyaman. Faktor keamanan, kenyamanan, keandalan, kemudahan akses, dan kecepatan adalah parameter bagaimana suatu sistem transportasi dapat dinyatakan baik atau tidak. Secara tegas dapat dikatakan, transportasi juga didorong karena adanya peningkatan nilai dari benda atau orang apabila ada perpindahan dari tempatasal ke tempat tujuan. Tujuan untuk mengetahui karakteristik penumpang dan karakteristik perjalanan dengan menguji variabel penumpang dan variabel perjalanan. Hasil dari penelitian ini adalah variasi penumpang pada pagi hari sangat bervariasi dengan persentase terbesar didominasi oleh perempuan, begitu juga dengan siang dan sore hari persentase terbesar didominasi oleh perempuan. Variabel perjalanan pada pagi hari juga sangat bervariasi dengan persentase terbesar didominasi oleh rantai perjalanan, pada siang hari oleh waktu tempuh saat macet, dan pada sore hari oleh frekuensi menggunakan mikrolet.
\end{abstract}

Kata Kunci : angkutan kota, karateristik, penumpang, perjalanan

\section{ABSTRACT}

A good measure of public transportation service are safe, fast, cheap and convenient service. Safety, comfort, reliability, ease of access, and speed are the parameters of how a transportation system can be stated as good or not. Strictly speaking, transportation is also encouraged because of the increased value of objects or people when there is a move from the place of origin to the destination. The aim is to determine the characteristics of the passengers and the characteristics of the trip by testing the passenger and trip variables. The results of this study are the variation of passengers in the morning varies greatly with the largest percentage dominated by female sex, as well as afternoon and evening the largest percentage is dominated by female sex. Travel variables in the morning also vary greatly with the largest percentage being dominated by the travel chain, during the daytime by traffic jams, and in the afternoon by the frequency of using a microbus.

Keywords: : city transportation, characteristics, passengers, travel

\section{PENDAHULUAN}

Angkutan perkotaan adalah angkutan dari satu tempat ke tempat lain dalam kawasan perkotaan yang terikat dalam trayek Tujuan utama keberadaan angkutan kota adalah untuk menyelenggarakan pelayanan yang baik dan layak bagi masyarakat.

Karakteristik penumpang merupakan pergerakan seseorang dalam suatu daerah dengan satu atau beberapa moda, dan dengan asal serta satu tujuan.

Setiap tahunnya, permintaan terhadap jasa transportasi ini semakin meningkat. Mengingat, pembangunan dan perkembangan suatu daerah transportasi memegang peranan yang sangat penting dalam kaitannya memobilisasi pergerakan arus orang dan barang/jasa. Hal ini juga dapat menjadi indikasi maju atau tidaknya suatu daerah, dengan melihat bagaimana suatu sistem transportasi mampu memenuhi kebutuhan penduduknya. Faktor keamanan, kenyamanan, keandalan, kemudahan akses, dan kecepatan adalah parameter bagaimana suatu sistem transportasi dapat dinyatakan baik atau tidak [1]. Secara tegas dapat dikatakan,transportasi juga didorong karena adanya peningkatan value dari benda atau orang apabila ada perpindahan dari tempat asal ke tempat tujuan. Fenomena ini terjadi juga di Kota Makassar.

Selain permasalah diatas, karateristik penumpang yang menggunakan angkutan umum perlu diketahui, untuk mendapatkan variasi-variasi penumpang yang 
menggunakan angkutan umum untuk perencanaan operasional pelayanan angkutan umum khususunya perencanaan sistem transportasi perkotaan.

Penumpang yang menggunakan angkutan kota trayek Sudiang - Sentral (trayek D) sangat bervariasi, mulai dari pekerja, mahasiswa dan pelajar serta ibu rumah tangga yang mulai digunakan penumpang dari pagi hari, siang hari, sore dan malam hari. Variasi-variasi inilah yang mendorong penulis untuk meneliti karakteristik penumpang ankutan kota (pete-pete) dengan mengambil kasus pada trayek $D$. Tujuan dilakukannya penelitian ini adalah untuk mengetahui karakteristik pelayanan untuk penumpang angkutan kotaMakassar Trayek Sudiang - Sentral dan untuk mengetahui karakteristik perjalanan penumpang pada Trayek D.

\section{Penelitian Terdahulu}

Analisis karakteristik perjalanan penumpang bus damri bandara dengan hasil persepsi penumpang untuk tingkat kenyamanan termasuk baik, maksud perjalanan didominasi tujuan ke rumah,penumpang bus bandara didominasi pria dengan usia 31-40 tahun, pendidikan terakhir $\mathrm{S} 1$, dan penghasilan ratarata $\mathrm{Rp}$. 2.500.000 - Rp.5.000.000 [2].

Kajian karakteristik pola perjalanan penumpang angkutan umum perkotaan (Yogyakarta) dengan hasil peelitian yaitu pengguna angkutan umum adalah masyarakat yang masih punya pilihan angkutan moda yang lain, jumlah anggota keluarga 3-5 orang, bangkitan dan tarikan terbesar berada di daerah Condong Catur Tunggal, Ngupasan, Condong Catur, Giwangan, dan Siduadi [3].

Evaluasi load factor dan karakteristik penumpang angkutan umum Bus Trans Jogja Jalur 2B menghasilkan nilai rata-rata load factor untuk setiap jalur di bawah 70\% serta karakteristik penumpang rata-rata termasuk golongan captive choice [4]

Study on the travel behavior of worker living in the Makassar suburban menghasilkan pengaruh waktu kedatangan dan waktu perjalanan sangat besar dibandingkan dengan biaya perjalanan [5].

Karakterisasi pelayanan sistem angkutan umum di Kotamadya Mataram menghasilkan ciri-ciri tidak beroperasi pada rute yang telah ditetapkan, penggunaan halte belum efisien, kecepatan operasional rendah, jadwal yang belum jelas, manajemen operasional rendah, dan kapasitas angkut rendah [6].

\section{METODOLOGI PENELITIAN}

Agar penelitian lebih sistematis dan dapat terlaksana lebih efektif dan efisisen, maka bagan alir dari penelitian yang digunakan dapat dilihat pada Gambar 1, berisi tahapan-tahapan dalam melakukan penelitian dimulai dengan melihat latar belakang, rumusan masalah, tujuan penelitian, manfaat penelitian dan batasan masalah untuk mendasari dilakukannya penelitian dimana angkutan kota (Mikrolet) Kota Makassar merupakan salah satu moda transportasi yang mendukung kegiatan socialekonomi penduduk makassar maupun daerahdaerah yang berada di sekitarnya.

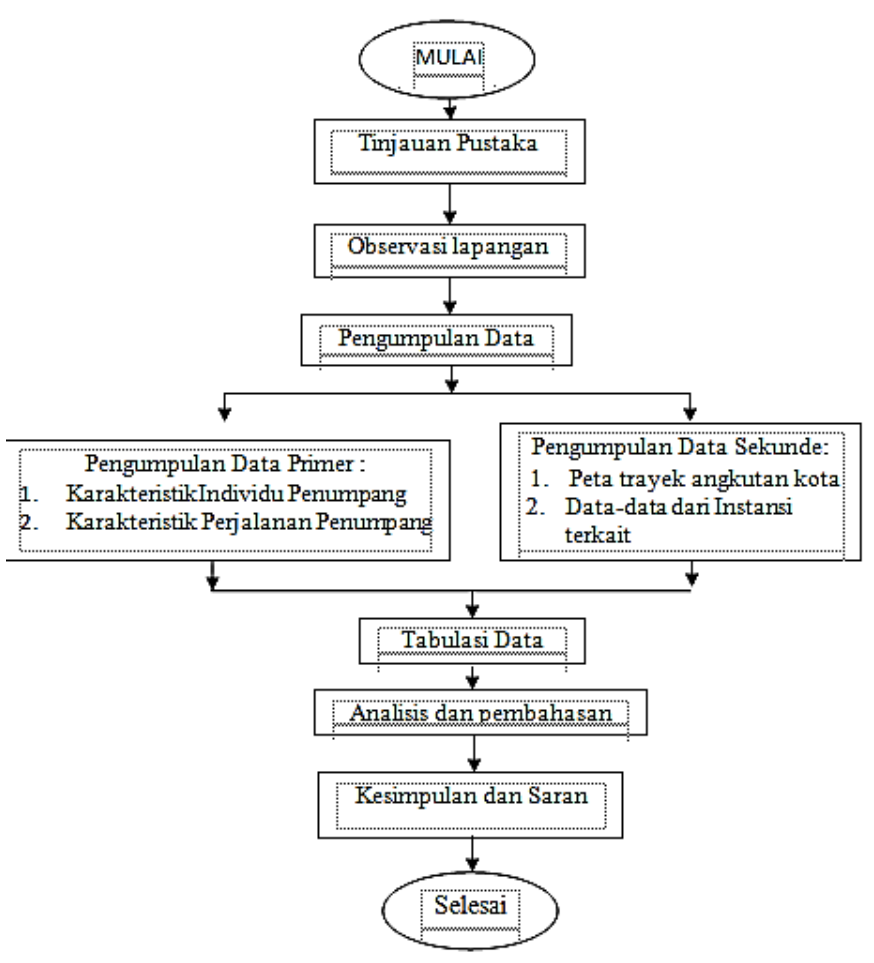

Gambar 1. Bagan alir penelitian

\section{Lokasi dan Waktu Penelitian}

Pengumpulan data dilakukan dengan menggunakan kuesioner yang terdiri atas serangkaian pertanyaan yang diajukan dan surveyor mencatat jawaban responden pada papan jawaban. Pengumpulan data responden dilakukan pada hari kerja dan hari libur yaitu hari senin sampai hari minggu. Pagi hari pada pukul 06.00 - 08.00, siang hari pada pukul $11.00-$ 13.00, dan sore hari pada pukul 16.00 - 18.00. Peta trayek Sudiang - Sentral dapat dilihat pada Gambar 2. 


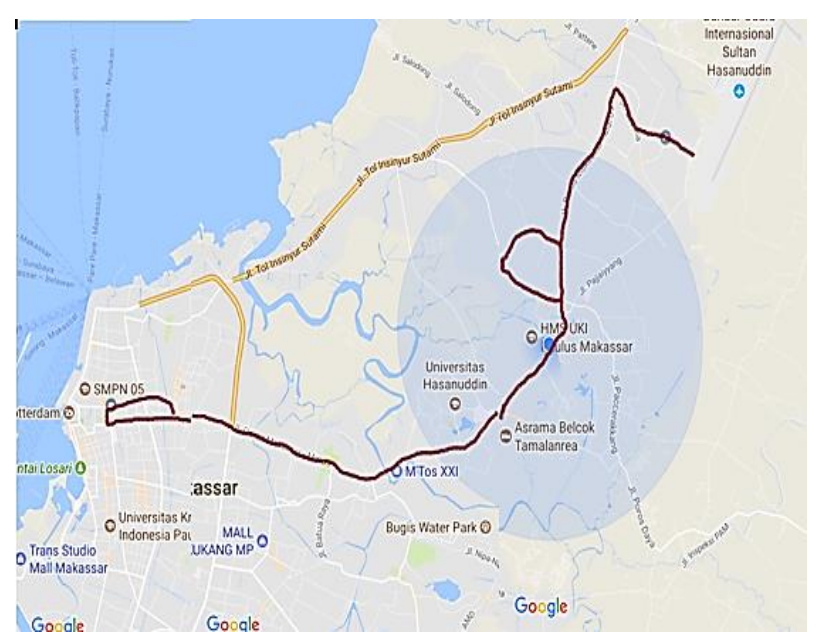

Gambar 2. Peta Trayek D Sudiang - Sentral Kota Makassar

\section{Tahap Pengumpulan Data}

Pengumpulan data berdasarkan sumber data dan metode pengumpulan data maka dibagi menjadi

a. Data primer merupakan data yang diperoleh dari peninjauan langsung di lapangan. Dimana data primer tersebut diperoleh dengan melakukan survey berupa kuesioner kepada penumpang mikrolet Trayek Sudiang - Sentral dan melakukan wawancara berdasarkan instrument kuesioner.

b. Data sekunder yaitu data yang diperoleh dari instansi - instansi terkait dan karya tulis terkait dengan penelitian ini.

\section{Metode Survey}

Dalam penelitian ini metode survey yang digunakan adalah wawancara secara langsung menggunakan kuesioner untuk mendapatkan data-data primer untuk mendapatkan karakteristik penumpang angkutan kota yang disajikan secara deskriptif. Pada survey ini dilakukan wawancara kepada penumpang angkutan kota pada trayek Sudiang-Sentral yang telah dipilih sebagai tempat pelaksanaan survey.

\section{Sampel}

Jumlah sampel yang diambil akan memberikan dampak keakuratan hasil akhir perhitungan. Semakin banyak sampel yang diambil dari suatu populasi maka kemungkinan keakuratan hasil perhitungan akan semakin baik.Sampel yang akan diambil yaitu 93 unit.
1. Memeriksa dan mengecek kelengkapan identitas pengisi

2. Memeriksa dan mengecek kelengkapan data, memeriksa isi instrumen pengumpulan data

3. Mengecek macam-macam isian

b. Tabulasi Data

Data-data yang telah terkumpul kemudian ditabulasikan yaitu menguraikan satu persatu datadata yang ada. Data dari tiap-tiap kuesioner kemudian dikelompokkan pada angket isian dan pedoman wawancara responden, dengan cara memberikan kode-kode tertentu dari tiap-tiap item instrument pengumpulan data yang selanjutnya diolah menggunakan aplikasi SPSS For Windows kemudian direkapitulasi menggunakan program EXCEL dan dimasukkan ke dalam bentuk tabel dan grafik.

\section{HASIL DAN PEMBAHASAN}

\section{Karakteristik Penumpang}

Jumlah karakteristik responden dalam penelitian ini berjumlah 524 orang, dimana 287 responden pada pagi hari, 32 responden pada siang hari dan 205 responden pada sore hari. Data kuesioner yang berisi beberapa pertanyaan yang dapat memberikan gambaran karakteristik penumpang angkutan kota Trayek Sudiang - Sentral Kota Makassar, yaitu antara lain Jenis kelamin, umur, jumlah anggota keluarga, anggota keluarga yang bekerja, status dalam keluarga, pekerjaan, pendidikan terakhir, pendapatan rata - rata perbulan, jumlah kendaraan motor, jumlah kendaraan beroda empat.

\section{a. Berdasarkan Jenis Kelamin}

Berdasarkan jenis kelamin yaitu pada pagi hari didominasi oleh perempuan dengan presentase sebesar $86.4 \%$ dari 287 orang, pada siang hari di dominasi oleh perempuan dengan presentase sebesar $87.5 \%$ dari 32 orang, danpada sore hari didominasi oleh perempuan dengan presentase sebesar $75.6 \%$ dari 205 orang. Karakteristik penumpang berdasarkan jenis kelamin dapat dilihat pada Gambar 3.

\section{Pengolahan Data dan Analisis Data}

a. Persiapan (kompilasi)

Kegiatan dalam langkah ini antara lain :

Karakteristik Penumpang Angkutan Umum Kota Trayek Sudiang - Sentral Makassar 


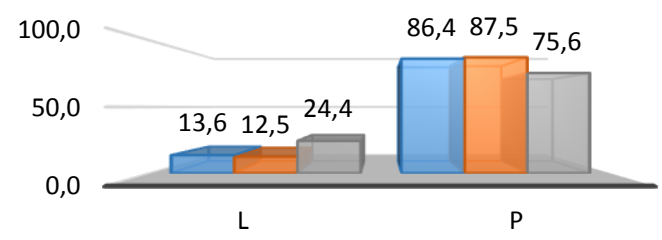

JENIS KELAMIN

$\square$ Waktu Pagi $\square$ Waktu Siang $\square$ Waktu Sore

Gambar 3. Grafik karakteristik penumpang berdasarkan jenis kelamin

\section{b. Berdasarkan Umur}

Presentase penumpang terbesar berdasarkan jumlah umur yaitu pada pagi hari umur 20 - 29 tahun sebesar $50.9 \%$, umur 30 - 39 tahun sebesar $23.3 \%$, umur $<20$ tahun sebesar $12.5 \%$, umur $40-50$ tahun sebesar $10.5 \%$ dan umur $>50$ tahun sebesar $2.4 \%$ yang mewakili 287 orang responden. Pada siang hari umur 20 - 29 tahun sebesar $43.3 \%$, umur $<20$ tahun sebesar $25,0 \%$, umur 30 - 39 tahun sebesar $12.5 \%$, umur > 50 tahun sebesar $12.5 \%$, dan umur $40-50$ tahun sebesar $6.3 \%$ yang mewakili 32 orang responden. Pada sore hari umur $20-29$ tahun 59,5 $\%$, umur 30 - 39 tahun sebesar $20,5 \%$, umur $<20$ tahun sebesar $13.7 \%$, umur 40 - 50 tahun sebesar $4.9 \%$ dan umur > 50 tahun sebesar $1.5 \%$ yang mewakili 205 orang responden. Karakteristik penumpang berdasarkan umum disajikan pada Gambar 4.

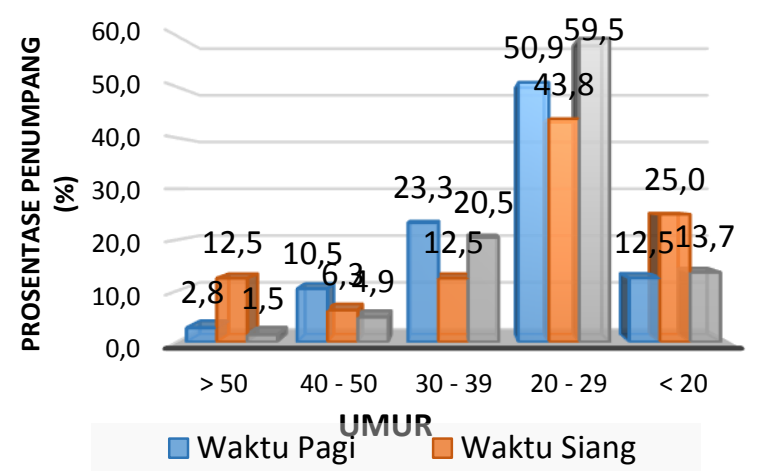

Gambar 4. Karakteristik penumpang berdasarkan jumlah umur

\section{c. Berdasarkan Jumlah Anggota Keluarga}

Presentase penumpang terbesar berdasarkan jumlah anggota keluarga yaitu pada pagi hari yang beranggotakan 4 orang sebesar $33.4 \%$, yang beranggotakan 3 orang sebesar $25.4 \%$, yang beranggotakan 5 orang sebesar $22.3 \%$, yang beranggotakan > 5 orang sebesar $12.2 \%$, yang beranggotakan 2 orang yaitu 5.9\% dan yang beranggotakan 1 orang sebesar $0.7 \%$ yang mewakili 287 orang responden. Pada siang hari yang beranggotakan > 5 orang sebesar $34.4 \%$, yang beranggotakan 3 orang sebesar 18.8\%, yang beranggotakan 5 orang sebesar $18.8 \%$, yang beranggotakan 4 orang sebesar $12.5 \%$, , yang beranggotakan 2 orang yaitu $9.4 \%$ dan yang beranggotakan 1 orang 6,3\% yang mewakili 32 responden. Pada sore hari yang beranggotakan 4 orang sebesar 31,7 \%, yang beranggotakan 3 orang sebesar $27.8 \%$, yang beranggotakan 5 orang sebesar $21.5 \%$, yang beranggotakan 1 orang sebesar 10,2 \%, yang beranggotakan 2 orang yaitu $6.8 \%$, yang beranggotakan dan > 5 orang sebesar $2.0 \%$ yang mewakili 205 responden. Karakteristik penumpang berdasarkan jumlah anggota keluarga dapat dilihat pada Gambar 5.
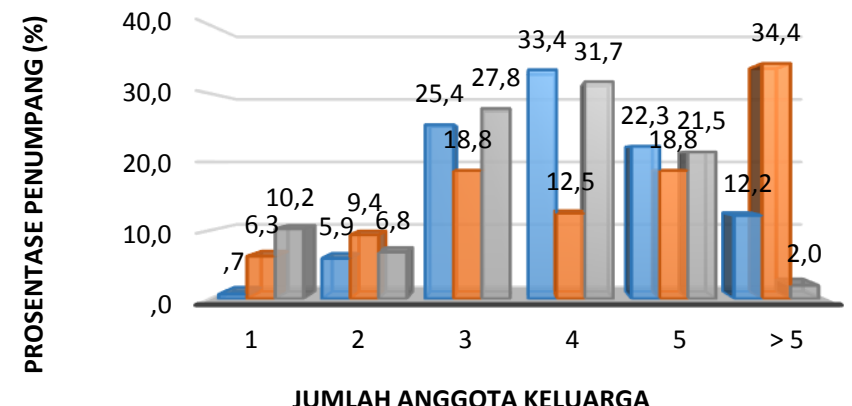

$\square$ Waktu Pagi $\quad \square$ Waktu Siang $\quad \square$ Waktu Sore

Gambar 5. Karakteristik penumpang berdasarkan jumlah anggota keluarga

\section{d. Berdasarkan Anggota Keluarga yang Bekerja}

Presentase penumpang terbesar berdasarkan anggota keluarga yang bekerja yaitu pada pagi hari yaitu 2 orang sebesar $56,4 \%, 3$ orang sebesar $18,8 \%$, 1 orang sebesar 16,4\%, 4 orang sebesar $4,2 \%, 5$ orang yaitu $1,7 \%$ dan $>5$ orang sebesar 0,3 $\%$ yang mewakili 287 responden. Pada siang hari 1 orang sebesar 37,5\%, 2 orang sebesar 25,5\%, 3 orang sebesar $21,9 \%$, 4 orang sebesar $12,5 \%$, dan 5 orang yaitu $3,1 \%$ yang mewakili 32 responden. Pada sore hari 3 orang sebesar 45,4\%, 4 orang sebesar $27,8,2$ orang sebesar $24,4 \%$, 1 orang sebesar $0,5 \%$, dan 5 orang sebesar 2,0\% yang mewakili 205 responden. Karakteristik penumpang berasarkan jumlah anggota keluarga yang bekerja dapat dlilihat pada Gambar 6. 


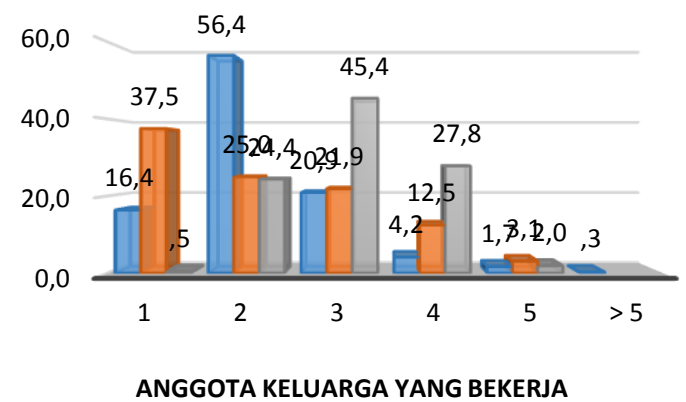

$\square$ Waktu Pagi $\square$ Waktu Siang $\square$ Waktu Sore

Gambar 6.Grafik karakteristik penumpang berdasarkan anggota keluarga yang bekerja

\section{e. Berdasarkan Status Dalam Keluarga}

Presentase penumpang terbesar berdasarkan status dalam keluarga yaitu pada pagi hari status anak sebesar $47.7 \%$, status istri sebesar $41.1 \%$, status saudara sebesar $7,3 \%$, dan status suami sebesar $3.8 \%$ yang mewakili 287 responden. Pada siang hari status anak sebesar $65.6 \%$, status istri sebesar 28.1 $\%$, status saudara sebesar $3.1 \%$, dan status suami sebesar $3.1 \%$ yang mewakili 32 responden. Pada sore hari status anak sebesar $42.9 \%$, status istri sebesar $37.1 \%$, status saudara sebesar $11.7 \%$, dan status suami sebesar 8.3\% yang mewakili 205 responden. Karakteristik penumpang berdasarkan status dalam keluarga dapat dilihat pada Gambar 7.

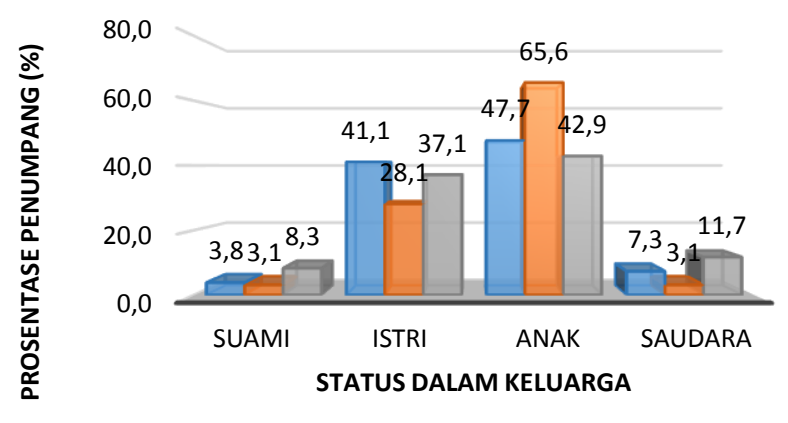

$\square$ Waktu Pagi $\square$ Waktu Siang $\square$ Waktu Sore

Gambar 7. Grafik karakteristik penumpang berdasarkan status dalam keluarga

\section{f. Berdasarkan Pekerjaan}

Presentase penumpang terbesar berdasarkan jenis pekerjaan yaitu pada pagi hari didominasi oleh swasta sebesar 27.5.\%, pelajar/mahasiswa sebesar $24.4 \%$, wiraswasta sebesar $19.9 \%$, PNS sebesar $17.1 \%$ dan pekerjaan lainnya sebesar $10.8 \%$ yang mewakili 287 responden. Pada siang hari didominasi oleh pekerjaan lainnya sebesar 34.4\%, pelajar/mahasiswa sebesar $31.3 \%$, swasta sebesar $15.6 \%$, wiraswasta sebesar $12.5 \%$, dan PNS sebesar $6.3 \%$ yang mewakili 32 responden. Pada sore hari didominasi oleh wiraswasta sebesar $37.1 \%$, pelajar/mahasiswa sebesar $22.9 \%$, swasta sebesar $19.0 \%$, PNS sebesar $16.6 \%$ dan pekerjaan lainnya sebesar 4.4\% yang mewakili 205 responden. Karakteristik penumpang berdasarkan pekerjaan disajikan pada Gambar 8.

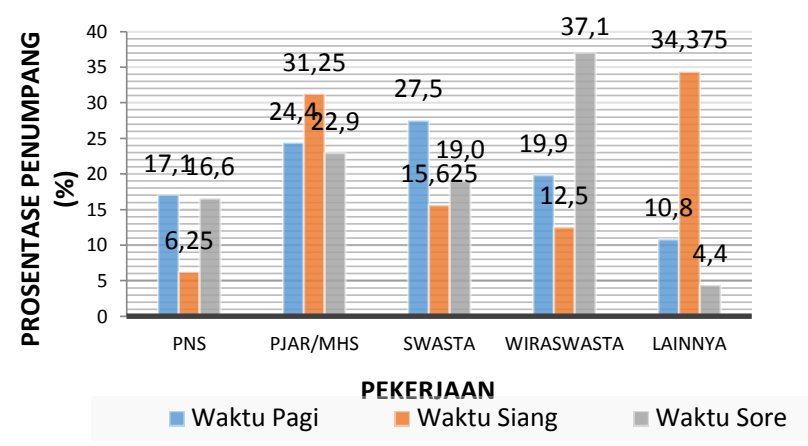

Gambar 8.Karakteristik penumpang berdasarkan jenis pekerjaan

\section{g. Berdasarkan Pendidikan Terakhir}

Presentase penumpang terbesar berdasarkan pendidikan terakhir yaitu pada pagi hari S1 sebesar $40.8 \%$, SLTA sebesar 37.3\%, diploma sebesar $13.6 \%$, pendidikan terakhir lainnya sebesar $5.6 \%$ dan S2 sebesar 1,4 \% yang mewakili 287 responden. Pada siang hari pendidikan terakhir lainnya sebesar $43,8 \%$, S1 sebesar 28,1 \%, SLTA sebesar $18.8 \%$, dan DIPLOMA sebesar $9.4 \%$ yang mewakili 32 responden. Pada sore hari SLTA sebesar 43.9\%, S1 sebesar $39,5 \%$, diploma sebesar $9.3 \%$, pendidikan terakhir lain sebesar $6.3 \%$ dan S2 sebesar $1.0 \%$ yang mewakili 205 responden. Karakteristik penumpang berdasarkan pendidikan terakhir dapat dilihat pada Gambar 9.

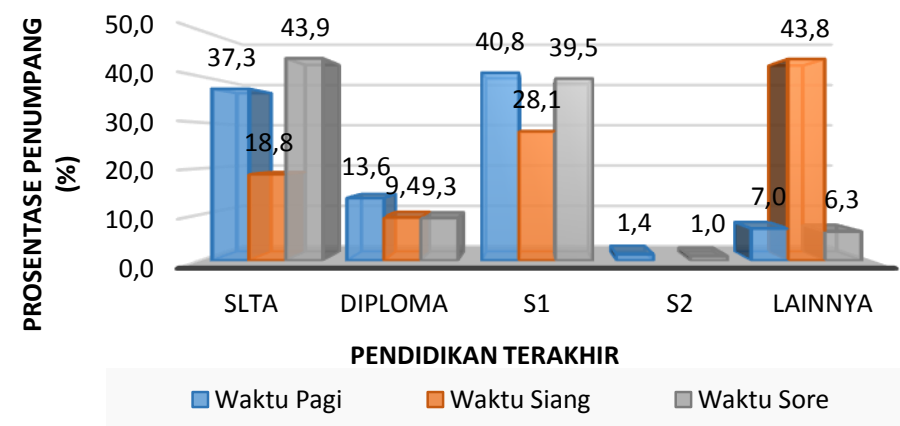

Gambar 9. Karakteristik penumpang berdasarkan pendidikan terakhir

h. Berdasarkan Pendapatan Rata - Rata Perbulan 
Presentase penumpang terbesar berdasarkan penghasilan rata-rata perbulan yaitu pada pagi hari 3 - 4 juta sebesar $37.6 \%$, tidak tetap sebesar $28.2 \%, 2$ - 3 juta sebesar $15.7 \%, 4$ - 5 sebesar $11.8 \%,<2$ juta sebesar $5.9 \%$, dan > 5 juta sebesar $0,7 \%$ yang mewakili 287 responden. Pada siang hari tidak tetap sebesar $53.1 \%$, 2 - 3 juta sebesar $15.6 \%, 3-4$ juta sebesar $12.5 \%$, < 2 juta sebesar $9.4 \%$, 4 - 5 sebesar $6.3 \%$, dan $>5$ juta sebesar $3.1 \%$ yang mewakili 32 responden. Pada pagi hari tidak tetap sebesar $35.1 \%, 3-4$ juta sebesar $22.0 \%, 2-3$ juta sebesar $17.6 \%,<2$ juta sebesar $9.4 \%, 4$ - 5 sebesar $6.3 \%$, dan > 5 juta sebesar 1.5\% yang mewakili 205 responden. Karakteristik penumpang berdasarkan penghasilan rata-rata per bulan disajikan pada Gambar 10.

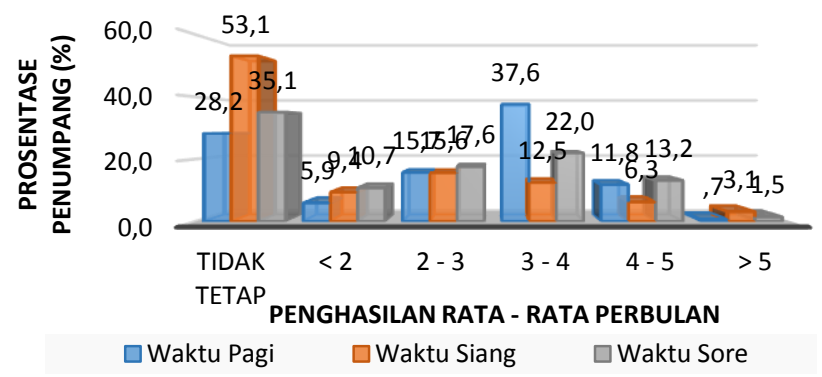

Gambar 10.Grafik karakteristik penumpang berdasarkan penghasilan per bulan

\section{i. Berdasarkan Jumlah Kepemilikan Sepeda Motor}

Presentase penumpang terbesar berdasarkan jumlah kepemilikan sepeda motor yaitu pada pagi hari 1 unit sebesar $54.7 \%$, 2 unit sebesar $15.0 \%$, 3 unit sebesar $2.1 \%$, dan tidak punya kendaraan motor sebesar $28.1 \%$ yang mewakili 287 responden. Pada siang hari 1 unit sebesar $34.4 \%$, 2 unit sebesar $34.4 \%$, 3 unit sebesar $3.1 \%$, dan tidak punya kendaraan motor sebesar $28.1 \%$ yang mewakili 32 responden. Pada sore hari 1 unit sebesar $48.3 \%$, 2 unit sebesar $30.2 \%, 3$ unit sebesar $1.5 \%$, dan tidak punya kendaraan motor sebesar $20.0 \%$ yang mewakili 205 responden. Karakteristik penumpang berdasarkan jumlah kepemilikan kendaraan sepeda motor disajikan pada Gambar 12.

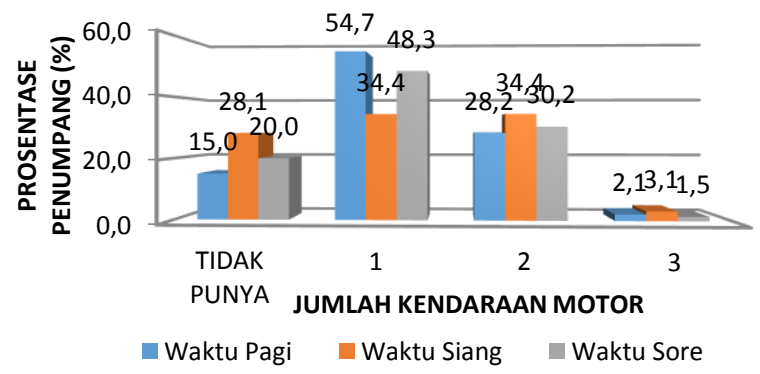

Gambar 11. Karakteristik penumpang

berdasarkan jumlah Kepemilikan sepeda motor j. Berdasarkan Jumlah Kepemilikan Kendaraan Beroda Empat

Presentase penumpang terbesar berdasarkan jumlah kepemilikan mobil yaitu pada pagi hari tidak punya kendaraan mobil sebesar $72.8 \%$, 1 unit sebesar 25.8 $\%$, 2 unit sebesar $1 \%$, dan 3 unit sebesar $0.3 \%$ yang mewakili 287 responden. Pada siang hari tidak punya kendaraan mobil sebesar $71.9 \%, 1$ unit sebesar 18,8 $\%$, dan 2 unit sebesar $9.4 \%$ yang mewakili 32 responden. Pada sore hari tidak punya kendaraan motor sebesar $75.1 \%$, 1 unit sebesar $21.5 \%$, dan 2 unit sebesar 3.4\% yang mewakili 205 responden. Karakteristik penumpang berdasarkan jumlah kepemilikan kendaraan roda empat dapat dilihat pada Gambar 12.

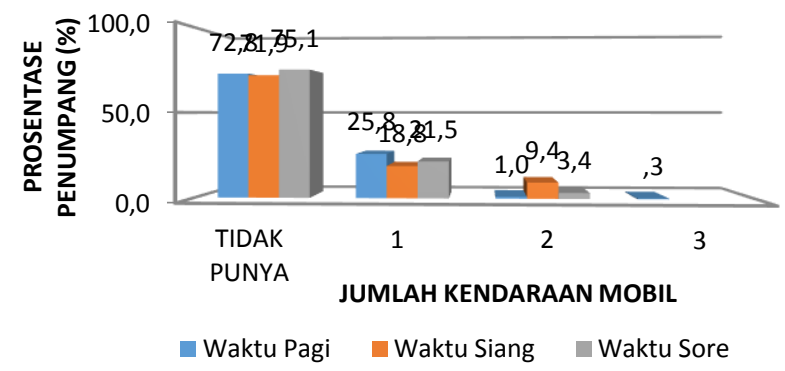

Gambar 12. Karakteristik penumpang berdasarkan jumlah kepemilikan mobil

\section{Karakteristik Perjalanan}

\section{a. Berdasarkan Rantai Perjalanan}

Presentase penumpang terbesar dalam melakukan rantai perjalanan yaitu pada pagi hari untuk ktr - rmh sebesar $73.2 \%$, untuk tempat kerja menuju rumah sebesar $12.9 \%$, untuk kantor menuju lokasi lain sebelum menuju rumah sebesar $7.7 \%$, dan untuk rumah sebesar $6.3 \%$ yang mewakili 287 responden. Pada siang hari untuk kantor ke rumah sebesar $71.9 \%$, untuk kantor ke rumah sebesar $3.1 \%$, untuk kantor menuju lokasi lain sebelum meuju ke rumah sebesar $9.4 \%$, dan untuk rumah sebesar $15.5 \%$ yang mewakili 32 responden. Pada sore hari untuk kantor rumah sebesar $33.2 \%$, untuk kantor antar rumah sebesar $16.6 \%$, untuk kantor - rumah sebesar $19.0 \%$, dan untuk rumah sebesar 31.2\% yang mewakili 205 responden. Karakteristik penumpang berdasarkan rantai perjalanan disajikan pada Gambar 13. 


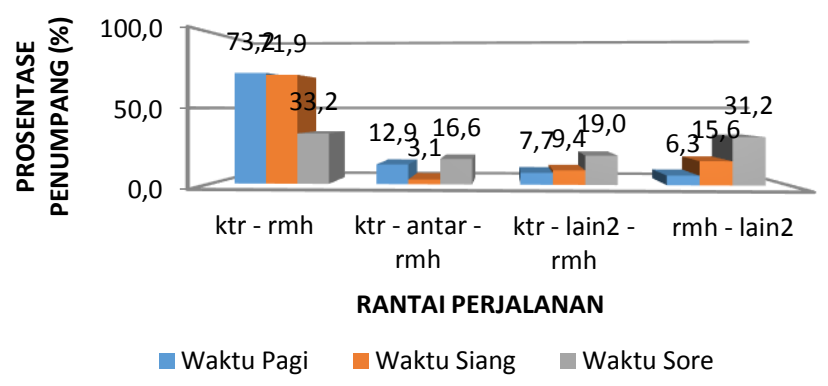

Gambar 13. Karakteristik perjalanan berdasarkan rantai perjalanan

\section{b. Berdasarkan Jarak Tempuh}

Presentase perjalanan terbesar berdasarkan jarak tempuh yaitu pada pagi hari untuk $10-14 \mathrm{~km}$ sebesar 39.7\%, 5 - 9km sebesar 30.3\%, $15-19 \mathrm{~km}$ sebesar $22.6 \%, 20$ - $24 \mathrm{~km}$ sebesar $7 \%$, dan $25-30$ kmsebesar $0,3 \%$ yang mewakili 287 responden. Pada siang hari untuk $10-14 \mathrm{~km}$ sebesar $37.5 \%, 5$ $9 \mathrm{~km}$ sebesar $37.5 \%, 15-19 \mathrm{~km}$ sebesar $12.5 \%$, dan 20 - $24 \mathrm{~km}$ sebesar $12.5 \%$ yang mewakili 32 responden. Pada sore hari untuk $10-14 \mathrm{~km}$ sebesar $42.9 \%, 5$ - $9 \mathrm{~km}$ sebesar $30.2 \%, 15-19 \mathrm{~km}$ sebesar $24.4 \%$, 20 - $24 \mathrm{~km}$ sebesar $2.0 \%$, dan $25-30 \mathrm{~km}$ sebesar $0.5 \%$ yang mewakili 205 responden. Karakteristik penumpang berdasarkan jarak tempuh dapat dilihat pada Gambar 14.

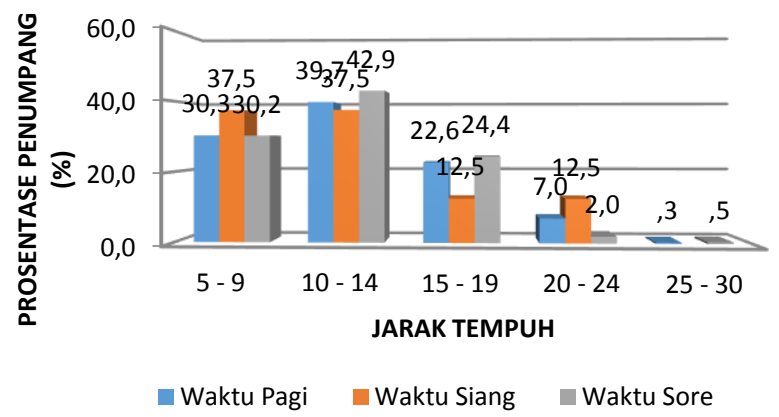

Gambar 14. Karakteristik perjalanan berdasarkan jarak tempuh

\section{c. Berdasarkan Waktu Berangkat}

Presentase perjalanan terbesar berdasarkan waktu berangkat pagi yaitu untuk pukul $<06.00$ sebesar 3.5 $\%$, untuk pukul $06.01-06.20$ sebesar $26.5 \%$, untuk pukul 06.21 - 06.40 sebesar $39.0 \%$, untuk pukul 06.41 - 07.00 sebesar $17.1 \%$, untuk pukul 07.01 07.20 sebesar $8.3 \%$, dan untuk pukul $07.21-07.40$ sebesar $5.6 \%$ yang mewakili 287 responden.

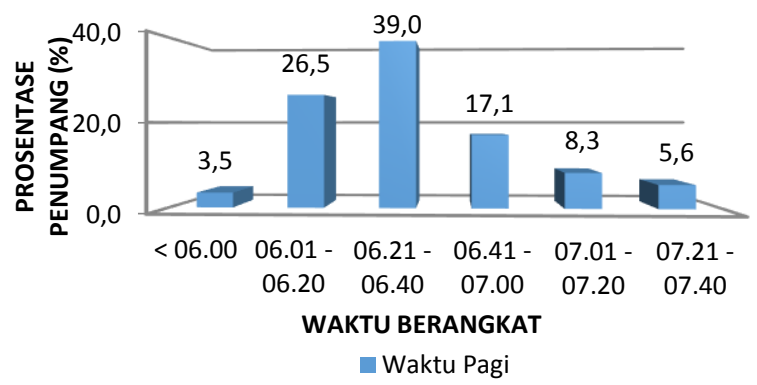

Gambar 15. Grafik karakteristik perjalanan berdasarkan waktu berangkat pagi hari

Presentase perjalanan terbesar berdasarkan waktu berangkat siang yaitu untuk sebelumpukul 11.00 sebesar $21.9 \%$, untuk pukul 11.01 - 11.20 sebesar $37.5 \%$, untuk pukul $11.21-11.40$ sebesar $21.8 \%$, untuk pukul $11.41-12.00$ sebesar $3.1 \%$, untuk pukul 12.01 - 12.20 sebesar $6.3 \%$, dan untuk pukul 12.21 12.40 sebesar $9.4 \%$ yang mewakili 32 responden. Karakteristik penumpang berdasarkan waktu perjalanan siang disajikan pada Gambar 16.

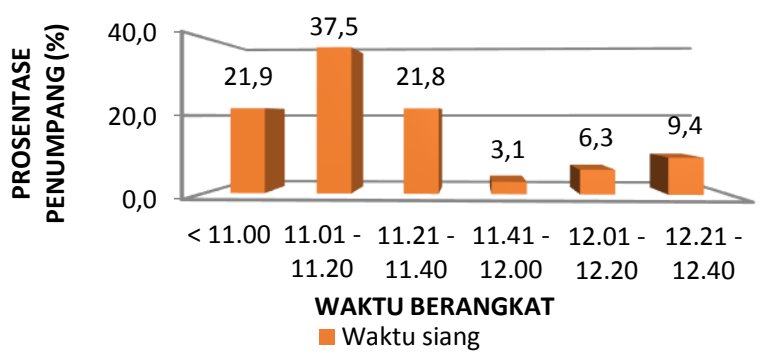

Gambar 16. Karakteristik perjalanan berdasarkan waktu berangkat siang

Presentase perjalanan terbesar berdasarkan waktu berangkat siang yaitu untuk sebelum pukul 16.00 sebesar $24.9 \%$, untuk pukul $16.01-16.20$ sebesar $35.6 \%$, untuk pukul $16.21-16.40$ sebesar $24.9 \%$, untuk pukul $16.41-17.00$ sebesar $9.3 \%$, untuk pukul 17.01 - 17.20 sebesar $4.4 \%$, dan untuk pukul 17.21 17.40 sebesar $1.0 \%$ yang mewakili 205 responden. Karakteristik penumpang berdasarkan waktu berangkat sore hari disajikan pada Gambar 17.

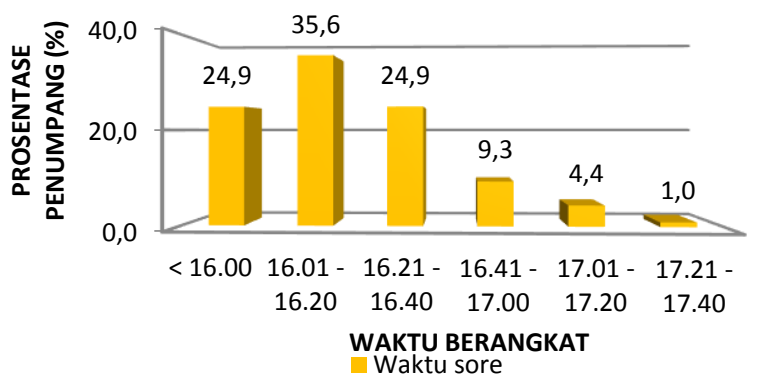

Gambar 17. Karakteristik perjalanan berdasarkan waktu berangkat sore

d. Berdasarkan Waktu Tiba di Tempat Tujuan 
Presentase perjalanan terbesar berdasarkan waktu tiba pagi yaitu untuk pukul 06.30 - 06.45 sebesar 7.0 $\%$, untuk pukul 06.46 - 07.00 sebesar $16.0 \%$, untuk pukul $07.01-07.15$ sebesar $21.6 \%$, untuk pukul 07.16 - 07.30 sebesar $33.1 \%$, untuk pukul 07.31 07.45 sebesar $10.5 \%$, untuk pukul $07.46-08.00$ sebesar $7.3 \%$ dan untuk setelah pukul 08.00 sebesar $7.3 \%$ yang mewakili 287 responden. Karakateristik perjalanan penumpang berdasarkan waktu tiba pagi hari dapat dilihat pada Gambar 18.

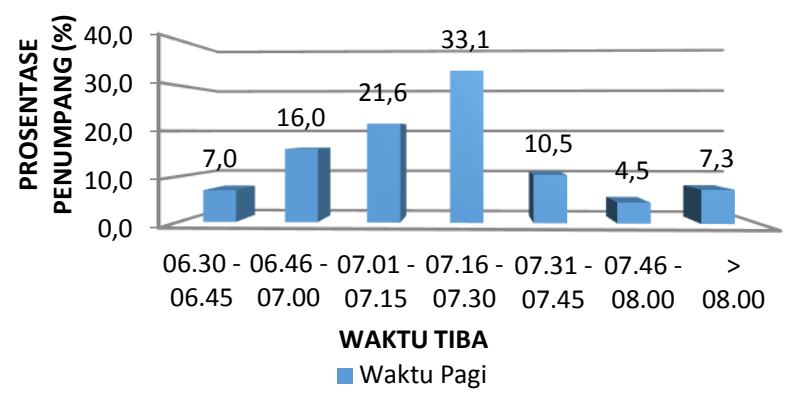

Gambar 18. Karakteristik perjalanan berdasarkan waktu tiba pagi

Presentase perjalanan terbesar berdasarkan waktu tiba siang yaitu untuk pukul 11.30 - 11.45 sebesar 25,0 \%, untuk pukul 11.46 - 12.00 sebesar 18.8\%, untuk pukul $12.01-12.15$ sebesar $12.5 \%$, untuk pukul 12.16 - 12.30 sebesar 15,6 \%, untuk pukul 12.31 - 12.45 sebesar $12.5 \%$, untuk pukul 12.46 13.00 sebesar $3,1 \%$ dan untuk setelah pukul 13.00 sebesar $12.5 \%$ yang mewakili 32 responden.

Presentase perjalanan terbesar berdasarkan waktu tiba sore yaitu untuk pukul 16.30 - 16.45 sebesar $17,1 \%$, untuk pukul 16.46 - 17.00 sebesar 18,0\%, untuk pukul $17.01-17.15$ sebesar 30,2 \%, untuk pukul 17.16 - 17.30 sebesar $19,0 \%$, untuk pukul 17.31 - 17.45sebesar 8,3 \%, untuk pukul 17.46 18.00 sebesar 5,9\% dan untuk pukul > 13.00 sebesar 1,5 \% yang mewakili 205 responden. Karakteristik perjalanan berdasarkan waktu tiba sore hari dapat dilihat pada Gambar 19.

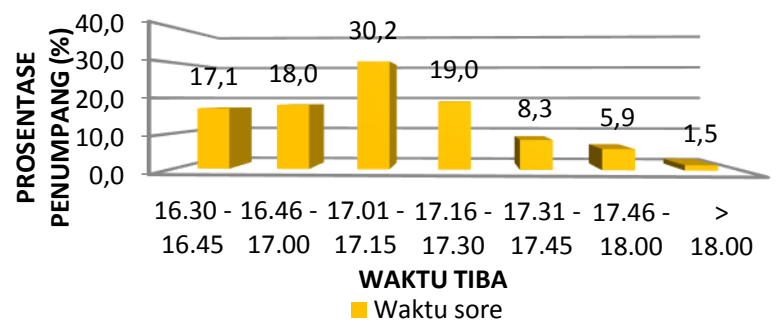

Gambar 19. Karakteristik perjalanan berdasarkan waktu tiba sore

\section{e. Berdasarkan Waktu Tempuh}

Berdasarkan Gambar 21 presentase penumpang terbesar berdasarkan waktu tempuh normal yaitu pada pagi hari untuk 21 - 30 menit sebesar 32,4\%, untuk 31 - 40 menit sebesar 30,7 \%, untuk $10-20$ menit sebesar $22,0 \%$, untuk 41 - 50 menit sebesar $10,8 \%$, untuk 51 - 60 menit sebesar $3,1 \%$, untuk 71 - 80 menit sebesar $0.7 \%$, dan untuk pukul $61-70$ menit sebesar $0.3 \%$ yang mewakili 287 responden. Pada siang hari untuk 10 - 20 menitsebesar $31.3 \%$, untuk 31 - 40 menit sebesar $28,1 \%$, untuk 21 - 30 menit sebesar $18.8 \%$, untuk 41 - 50 menit sebesar $9.4 \%$, untuk 51 - 60 menit sebesar $6,3 \%$, dan untuk 71 - 80 menit sebesar $6.3 \%$ yang mewakili 32 responden. Pada sore hari untuk 21 - 30 menit sebesar $37.6 \%$, untuk $10-20$ menit sebesar $25.9 \%$ untuk 31 - 40 menit sebesar $16.6 \%$, untuk 41 - 50 menit sebesar $10.7 \%$, untuk 51 - 60 menit sebesar $7,8 \%$, dan untuk $71-80$ menit sebesar $1.5 \%$ yang mewakili 205 responden. Karakteristik perjalanan berdasarkan waktu tempuh normal disajikan pada Gambar 20.

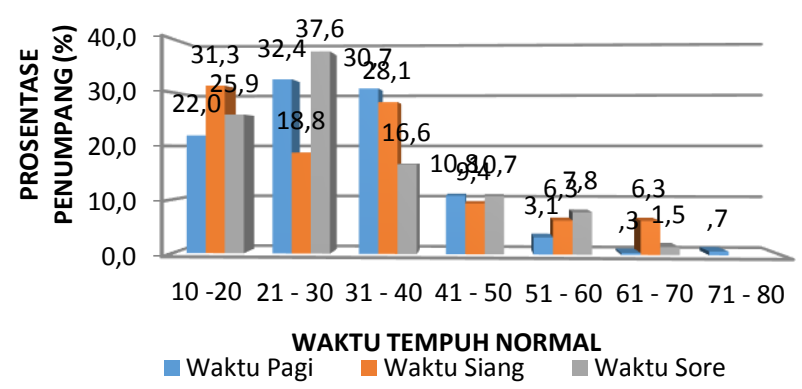

Gambar 20. Karakteristik perjalanan berdasarkan waktu tempuh normal

\section{f. Berdasarkan Waktu Tempuh Kondisi Macet}

Presentase penumpang terbesar berdasarkan waktu tempuh saat macet yaitu pada pagi hari untuk 41 60 menit sebesar $44.3 \%$, untuk 20 - 40 menit sebesar $37.6 \%$, untuk 61 - 80 menit sebesar 15.7 , untuk 81 100 menit sebesar $1.4 \%$, untuk 121 - 140 menit sebesar $0.7 \%$, dan untuk pukul 101 - 120 menit sebesar $0.3 \%$ yang mewakili 287 responden. Pada siang hari untuk 20 - 40 menit sebesar 40,6 \%, untuk 41 - 60 menit sebesar $31.3 \%$, untuk 61 - 80 menit sebesar $21.9 \%$, dan untuk 81 - 100 menit sebesar $6.3 \%$ yang mewakili 32 responden. Pada sore hari untuk 41 - 60 menit sebesar $42.9 \%$, untuk 20 - 40 menit sebesar $40.0 \%$, untuk 61 - 80 menit sebesar $14.1 \%$, dan untuk 81 - 100 menit sebesar $2.9 \%$ yang mewakili 205 responden. Karakteristik berdasarkan waktu tempuh kondisi macet disajikan pada Gambar 21. 


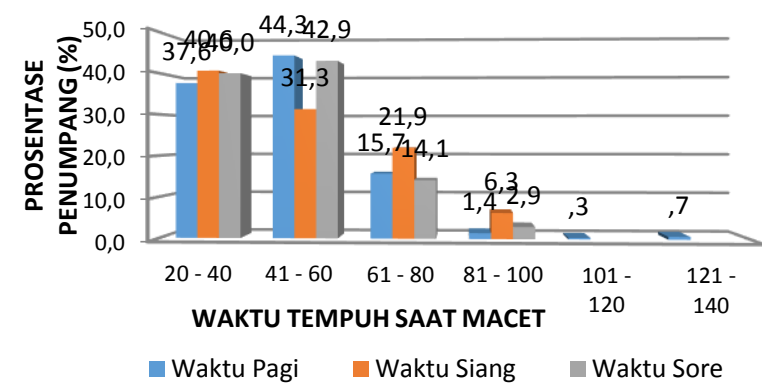

Gambar 21. Karakteristik perjalanan berdasarkan waktu tempuh kondisi macet

g. Berdasarkan Frekuensi Menggunakan Angkutan Umum Mikrolet Per Minggu

Presentase penumpang terbesar berdasarkan frekuensi menggunakan angkutan umum per minggu yaitu pada pagi hari untuk $2-6$ kali sebesar $35.5 \%$, untuk $>6$ kali sebesar $32.8 \%$, dan untuk $<2$ kali sebesar $31.7 \%$ yang mewakili 287 responden. Pada siang hari untuk $>6$ kali sebesar $59.4 \%$, untuk $2-6$ kali sebesar $37.5 \%$, dan untuk < 2 kali sebesar $3.1 \%$ yang mewakili 32 responden. Pada sore hari untuk 2 - 6 kali sebesar $71.7 \%$, untuk > 6 kali sebesar $27.3 \%$, dan untuk $<2$ kali sebesar $1.0 \%$ yang mewakili 205 responden. Karakteristik perjalanan penumpang berdasarkan frekuensi menggunakan angkutan umum per minggu disajikan pada Gambar 22.

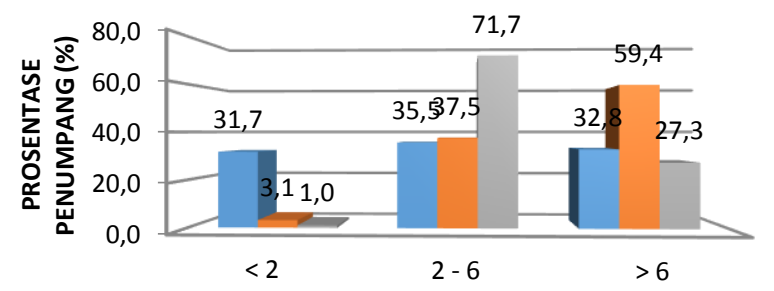

FREKUENSI MENGGUNAKAN MIKROLET PERMINGGU Waktu Pagi Waktu Siang Waktu Sore

Gambar 22. Karakteristik perjalanan berdasarkan frekuensi menggunakan angkutan umum mikrolet per minggu

Dari 287 responden diperolah hasil perempuan dengan presentase sebesar $86.4 \%$, untuk umur didominasi oleh 20 - 29 tahun dengan presentase sebesar $59.9 \%$, untuk jumlah anggota keluarga persentase sebesar $33.4 \%$ rata - rata memiliki 4 anggota keluarga, untuk anggota keluarga yang bekerja presentase sebesar $56.4 \%$ dengan 2 anggota keluarga yang bekerja, untuk status dalam keluarga didominasi oleh anak dengan presentase sebesar $47.7 \%$, pekerjaan dengan presentase sebesar $27.5 \%$ didominasi oleh swasta, pendidikan terakhir untuk S1 dengan presentase sebesar $40.8 \%$ , penghasilan rata - rata perbulan didominasi oleh penghasilan rata - rata 3 - 4 juta dengan presentase sebesar $37.6 \%$, jumlah kendaraan bermotor yang dimiliki oleh penumpang memiliki presentase sebesar $5.7 \%$ rata - rata hanya memiliki 1 unit kendaraan bemotor, jumlah kendaraan mobil yang dimiliki oleh penumpang dengan presentase $72.8 \%$ rata - rata tidak memiliki kendaraan mobil. Moda yang digunakan oleh penumpang dengan presentase $77.1 \%$ rata -rata memilih mikrolet sebagai moda utama.Rantai perjalanan penumpang, penumpang rata - rata melakukan perjalanan dari tempat kerja ke rumah atau sebaliknya. Jarak tempuh dengan presentase sebesar $39.7 \%$ dengan jarak rata-rata 10 $-14 \mathrm{~km}$. Penumpang rata - rata menggunakan waktu berangkat pada pukul 06.21- 06.40 dan waktu tiba di tempat tujuan pada pukul 07.16 - 07.30. Waktu tempuh normal dengan presentase sebesar $32.4 \%$ ditempuh dengan waktu 21-30 menit, waktu tempuh macet dengan presentase sebesar $44.3 \%$ ditempuh dengan waktu 41-60 menit. Frekuensi menggunakan mikrolet perminggu dengan presentase sebesar $35.5 \%$ penumpang menggunakan mikrolet 2 - 6 kali.

Dari 32 responden diperolah hasil perempuan dengan presentase sebesar $87.5 \%$, untuk umur didominasi oleh 20 - 29 tahun dengan presentase sebesar $43.8 \%$, untuk jumlah anggota keluarga persentase sebesar $34.4 \%$ rata - rata memiliki $>5$ anggota keluarga, untuk anggota keluarga yang bekerja presentase sebesar $37.5 \%$ dengan 1 anggota keluarga yang bekerja, untuk status dalam keluarga didominasi oleh anak dengan presentase sebesar $65,6 \%$, pekerjaan dengan presentase sebesar $34.4 \%$ didominasi oleh pekerjaan lain, pendidikan terakhir lainnya dengan presentase sebesar $43.8 \%$, penghasilan rata - rata perbulan didominasi oleh penghasilan rata - rata perbulan dengan presentase sebesar $53.1 \%$ dengan penghasilan yang tidak tetap, jumlah kendaraan bermotor yang dimiliki oleh penumpang memiliki presentase sebesar $34.4 \%$ rata - rata hanya memiliki 1 unit kendaraan bemotor, jumlah kendaraan mobil yang dimiliki oleh penumpang dengan presentase $71.9 \%$ rata - rata tidak memiliki kendaraan mobil. Moda yang digunakan oleh penumpang dengan presentase $90.6 \%$ rata -rata memilih mikrolet sebagai moda utama.Rantai perjalanan penumpang penumpang rata - rata melakukan perjalanan dari tempat kerja ke rumah dan sebaliknya. Jarak tempuh dengan presentase sebesar $37.5 \%$ dengan jarak rata-rata $10-14$ dan 5-9 km. Penumpang rata - rata menggunakan waktu berangkat pada pukul 11.01 11.20 dan waktu tiba di tempat tujuan pada pukul 11.30 - 11.45. Waktu tempuh normal dengan presentase sebesar $31.3 \%$ ditempuh dengan waktu 10-20 menit, waktu tempuh macet dengan 
presentase sebesar $40.6 \%$ ditempuh dengan waktu 20-40 menit. Frekuensi menggunakan mikrolet perminggu dengan presentase sebesar $59.4 \%$ penumpang menggunakan mikrolet $>6$ Kali.

Dari 205 responden diperoleh hasil perempuan dengan presentase sebesar $75.6 \%$, untuk umur didominasi oleh 20 - 29 tahun dengan presentase sebesar 59.5\%, untuk jumlah anggota keluarga persentase sebesar $31.7 \%$ rata - rata memiliki 4 anggota keluarga, untuk anggota keluarga yang bekerja presentase sebesar $45.4 \%$ dengan 3 anggota keluarga yang bekerja, untuk status dalam keluarga didominasi oleh anak dengan presentase sebesar $42.9 \%$, pekerjaan dengan presentase sebesar $37,1 \%$ didominasi oleh wiraswasta, pendidikan terakhir SLTA dengan presentase sebesar $43.9 \%$, penghasilan rata - rata perbulan didominasi oleh penghasilan rata - rata perbulan dengan presentase sebesar $35.1 \%$ dengan penghasilan yang tidak tetap, jumlah kendaraan bermotor yang dimiliki oleh penumpang memiliki presentase sebesar $43.2 \%$ rata - rata hanya memiliki 1 unit kendaraan bemotor, jumlah kendaraan mobil yang dimiliki oleh penumpang dengan presentase $79.1 \%$ rata - rata tidak memiliki kendaraan mobil. Moda yang digunakan oleh penumpang dengan presentase $77.6 \%$ rata -rata memilih mikrolet sebagai moda utama. Rantai perjalanan penumpang penumpang rata - rata melakukan perjalanan dari tempat kerja ke rumah dan sebaliknya. Jarak tempuh dengan presentase sebesar $42.9 \%$ dengan jarak rata-rata $10 \quad-14 \mathrm{~km}$. Penumpang rata - rata menggunakan waktu berangkat pada pukul 16.01 16.20 dan waktu tiba di tempat tujuan pada pukul 17.01 - 17.15. Waktu tempuh normal dengan presentase sebesar $27.6 \%$ ditempuh dengan waktu 21 - 30 menit, waktu tempuh macet dengan presentase sebesar 42,9\% ditempuh dengan waktu 41-60 menit. Frekuensi menggunakan mikrolet perminggu dengan presentase sebesar $71.7 \%$ penumpang menggunakan mikrolet 2 - 6 kali.

\section{KESIMPULAN}

Dari 287 responden, pada pagi hari karakteristik penumpang sangat bervariasi dengan persentase terbesar didominasi oleh perempuan.
Dari 32 responden, pada siang hari karakteristik penumpang sangat bervariasi dengan persentase terbesar didominasi oleh perempuan.

Dari 205 responden, pada sore hari karakteristik penumpang sangat bervariasi dengan persentase terbesar didominasi oleh perempuan.

Dari 287 responden, pada pagi hari karakteristik perjalanan penumpang sangat bervariasi dengan persentase terbesar dipengaruhi oleh rantai perjalanan.

Dari 32 responden, pada siang hari karakteristik perjalanan penumpang sangat bervariasi dengan persentase terbesar dipengaruhi oleh waktu tempuh kondisi macet.

Dari 205 responden, pada pagi hari karakteristik perjalanan penumpang sangat bervariasi dengan persentase terbesar dipengaruhi oleh frekuensi menggunakan angkutan kota per minggu.

\section{DAFTAR PUSTAKA}

[1] "Merencanakan Sistem Perangkutan / Suwardjoko Warpani." [Online]. Available: http://library.um.ac.id/free-

contents/index.php/buku/detail/merencanakansistem-perangkutan-suwardjoko-warpani17028.html.

[2] A. F. Mahmuda and M. I. Ramli, "Analisis Karakteristik Perjalanan Penumpang Bis Damri Bandara," p. 13.

[3] N. C. Kresnanto, "Kajian Karakteristik dan Pola Perjalanan Penumpang Angkutan Umum Perkotaan," vol. 3, no. 2, p. 11.

[4] "Evaluasi Load Factor dan Karakteristik Angkutan Umum Bus Trans Jogja Jalur 2B." [Online].

Available: http://repository.umy.ac.id/handle/123456789/60 07?show=full. [Accessed: 11-Dec-2019].

[5] R. Rachman, "Study of Commuter Travel Characteristics of Makassar Suburban," vol. 7, no. 2, p. 8, 2018.

[6] "Karakterisasi Pelayanan Sistem Angkutan Umum." [Online]. Available: https://fdokumen.com/document/karakterisasipelayanan-sistem-angkutan-umum-karakteristikmoda-angkutan-kota.html. 